\title{
Purely intramedullary spinal cord primitive neuroectodermal tumor: case report and review of the literature
}

\author{
A. Otero-Rodríguez; J. Hinojosa; J. Esparza; M.J. Muñoz; S. Iglesias; Y. Rodríguez-Gil and J.R. Ricoy* \\ Division of Pediatric Neurosurgery and *Department of Neuropathology. "12 de Octubre" Hospital. Madrid.
}

\section{Summary}

Introduction. Primitive neuroectodermal tumors (PNETs) are malign neoplasms of the central nervous system which mainly locate in cerebellum (medulloblastoma). Primary intraspinal PNETs are rare. Within this group, we have found ten cases of purely intramedullary PNETs (IPNETs). In this report, we describe a new IPNET case and review the literature about these infrequent intramedullary tumors.

Case report. A 17 month-old boy showed progressive decrease of motion in his lower extremities. Spine magnetic resonance imaging revealed an intramedullary expansive lesion from T3 to T10. A near-total removal was performed. The pathological diagnosis was PNET. Subsequent chemotherapy was recommended. Six months after operation, holocord progression has occurred.

Conclusion. IPNETs are uncommon tumors affecting children and young adults. They are characterized by recurrence, progression or intracranial dissemination. Outcome is dismal: most patients die within two years in spite of surgical resection followed by radiotherapy and chemotherapy.

KEYWORDS: Primitive neuroectodermal tumor. Spinal cord. Primary intramedullary.

Tumor neuroectodérmico primitivo espinal exclusivamente intramedular: caso clínico y revisión de la literatura

\section{Resumen}

Introducción. Los tumores neuroectodérmicos primitivos (PNETs) son neoplasias malignas del sistema nervioso central que principalmente se localizan a nivel del cerebelo (denominadas en este caso meduloblastomas). Son muy poco frecuentes los PNETs

Recibido: 19-04-07. Aceptado: 26-10-08 primarios intraespinales. Dentro de este grupo, solamente hemos encontrado diez casos de PNETs exclusivamente intramedulares. En este artículo, describimos un nuevo caso de IPNET y procedemos a revisar la literatura existente sobre este tipo de tumores.

Caso clínico. Se trata de un niño de 17 meses de edad que ha desarrollado una paraparesia progresiva. La resonancia magnética espinal muestra una lesión expansiva intramedular que se extiende desde $\mathrm{T} 3$ hasta T10. Se procedió a una extirpación macroscópica casi completa. El estudio anatomopatológico reveló un PNET. Se recomendó quimioterapia. Seis meses después de la cirugía, ha habido progresión a lo largo de la médula.

Conclusión. Los PNETs exclusivamente intramedulares son raras neoplasias que afectan a niños $\mathbf{y}$ adultos jóvenes. Se caracterizan por la recurrencia, progresión o diseminación intracraneal. Son procesos de muy mal pronóstico, ya que los pacientes mueren en los primeros dos años a pesar de la resección quirúrgica y posterior radioterapia y quimioterapia.

PALABRAS CLAVE: Tumor neuroectodérmico primitivo. Médula espinal. Primario intramedular

Introduction

Primitive neuroectodermal tumors (PNETs) are a group of malign neoplasms which were initially defined by Hart and Earle in $1973^{5}$.

The most common localization of these tumors is in the cerebellum (medulloblastoma); however, they can also arise in other sites of the central nervous system (CNS) such as the cerebral hemispheres, pineal gland, brain stem and spinal cord ${ }^{17}$.

Abreviaturas. CNS: central nervous system. GFAP: glial fibrillary acidic protein. IPNET: intramedullary primitive neuroectodermal tumor. MCNU: ranimustine. MRI: magnetic resonance imaging. NSE: neuron-specific enolase. PNET: primitive neuroectodermal tumor. VP-16: etoposide. WHO: World Health Organization. 


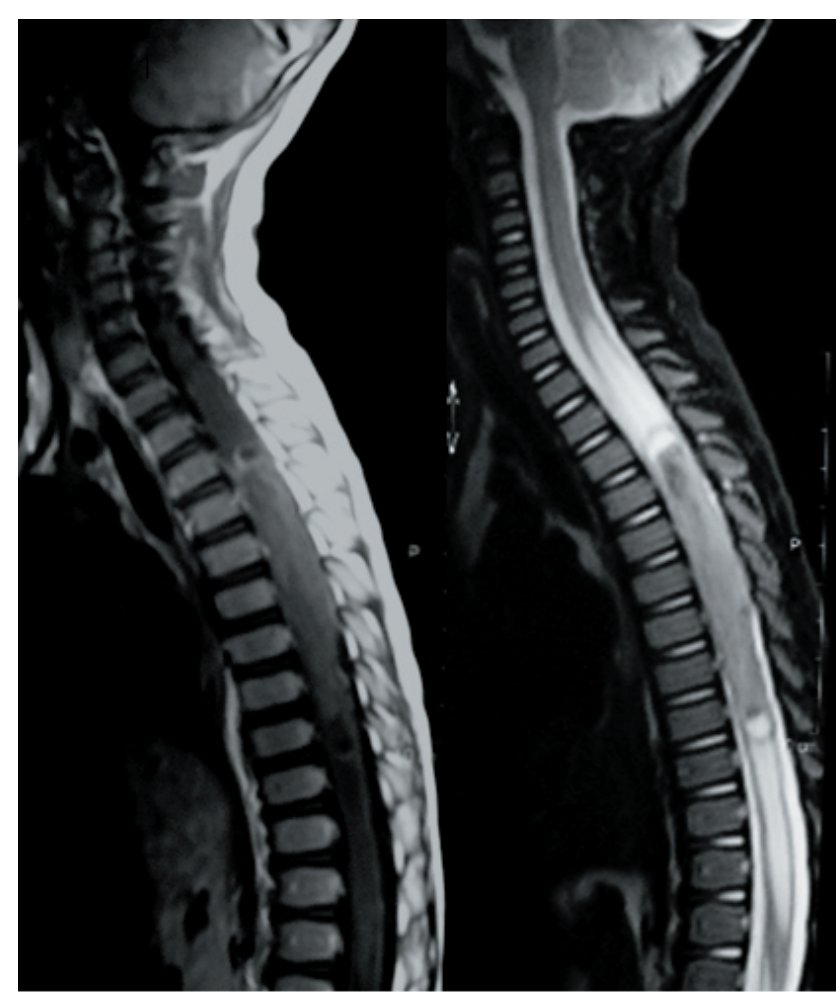

Figure 1. Preoperative spinal cord magnetic resonance imaging shows an expansive dilatation of the spinal cord that enhances unhomogeneously after administration of contrast (A) and is hyperintense in T2-weigthed image (B).

The occurrence of primary intraspinal PNET is rare. At this setting, intramedullary, extramedullary, intra-extramedullary and extradural have been described ${ }^{3}$. To our knowledge, only ten cases of purely intramedullary PNETs (IPNETs) have been previously reported. In this article, we describe a new purely IPNET and review all reports about these rare intramedullary neoplasms.

\section{Case report}

A previously healthy 17 month-old boy was admitted to our center because of progressive paraparesis. He was the product of an uncomplicated pregnancy and delivery. He had acquired autonomous deambulation at the age of 11 months.

One month before admission, and coinciding with an acute gastroenteritis, his parents referred that the infant showed a decreased motion in his lower extremities which had progressed over this time.

The neurological examination revealed paraparesis (grade of weakness $3 / 5$ at hips; $2 / 5$, at knees; and 1/5, at ankles). His knee and ankle reflexes were bilaterally brisk. Babinski's sign was positive bilaterally and the triple flexor

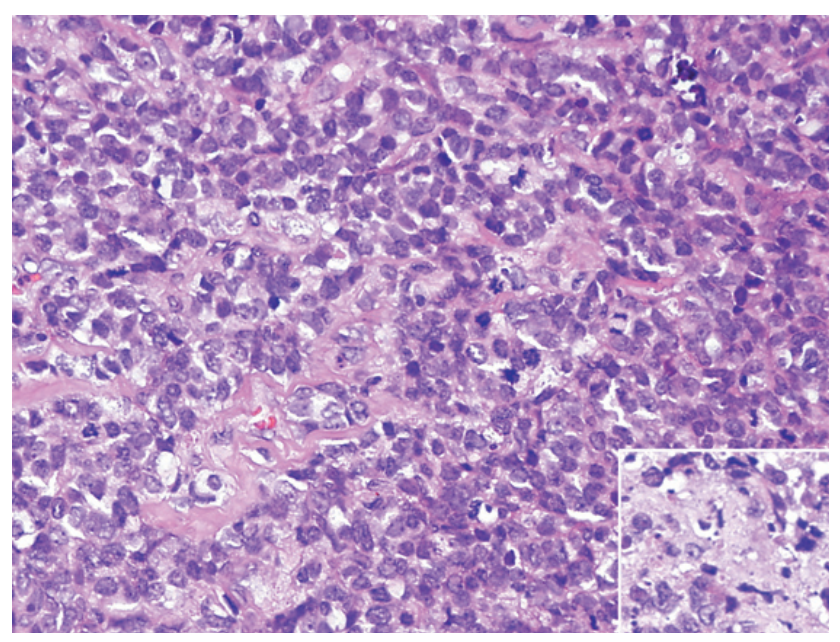

Figure 2. Highly cellular and poorly differentiated tumor, with mitosis figures (typical and atypical). Detail: areas of necrosis with karyorrhexis (hematoxylin and eosin; original magnification, x400).

response was evident at right lower extremity. Bilateral and prolonged clonus could be elicited. The abdominal cutaneous reflexes were abolished. Finally, at general exploration, the infant presented abdominal distension due to paralytic ileus and urinary retention.

Spine magnetic resonance imaging (MRI) showed an intramedullary expansive lesion which extended from T3 to T10. The tumor was isointense on T1-weighted MRI and hyperintense on T2-weighted MRI. It also showed an unhomogeneous and weak contrast enhancement (Figure 1).

An osteoplastic laminotomy was performed from T3 to T10. After durotomy and dorsal midline myelotomy, a grey-reddish, friable, bleeding and poorly demarcated tumor was seen. Near-total removal of the neoplasm was performed under the operating microscope.

Microscopic examination of biopsy fragments revealed a highly cellular, poorly differentiated neoplasm. The cells showed scanty cytoplasm and intense basophilic and pleomorphic nuclei; some nuclei were small and round and others were more prominent, irregular rims. Atypical mitosis, karyorrhexis and areas of necrosis were observed (Figure 2). The tumor had fibrillar stroma. Homer-Wright rosettes, ependymal canals or well-defined Flexner-Wintersteiner rosettes were not noted. Immunohistochemical staining for neuron-specific enolase (NSE) (dilution 1/100) was intensely positive and staining for glial fibrillary acidic protein (GFAP) (dilution 1/1800) was negative (Figure 3). The definitive histopathologic diagnosis was PNET.

In the postoperative course, the neurological condition initially worsened. Postoperative MRI of the head and spine (Figure 4) showed no further tumor localizations. Chemotherapy was indicated, using cisplatin, carbopla- 


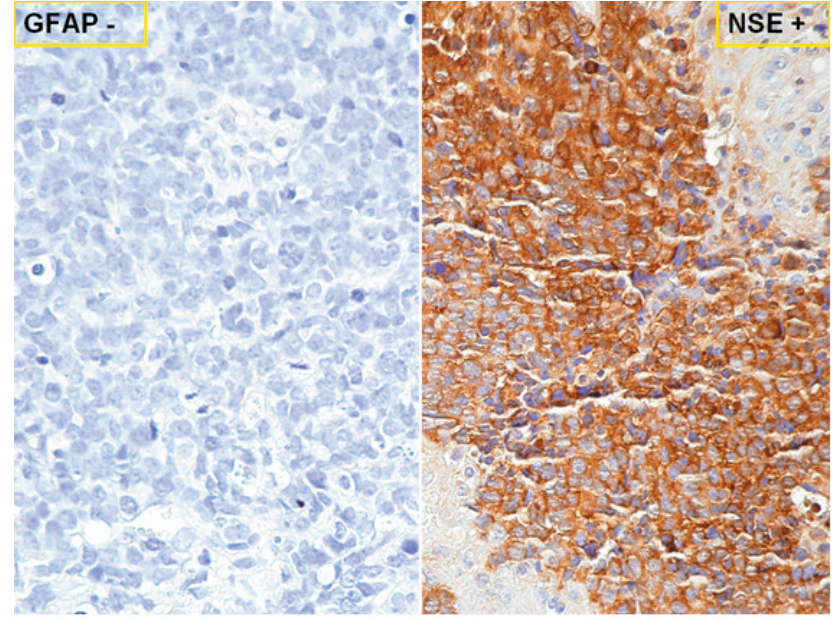

Figure 3. Immunihistochemical staining: glial fibrillary acidic protein (GFAP) negative (A) and neuron-specific enolase (NSE) positive (B), suggestive of neuronal differentiation.

tin, etoposide (VP-16), cyclophosphamide and high-dose methotrexate.

Twelve weeks after operation, the infant had clinically improved: he could crawl and his bowel and urologic dysfunctions had practically disappeared. Currently, six months after surgery, holocord progression is evident.

\section{Discussion}

PNETs are malign tumors that usually occur in the pediatric age. They are composed of highly undifferentiated neuroepithelial cells. The term PNET comprises various lesions that are histologically similar but are located throughout CNS. The most common location is the infratentorial region, in which the PNET is referred to as a medulloblastoma $^{17}$.

In 1973, Hart and Earle were the first who proposed the term "primitive neuroectodermal tumor" to describe a neoplasm which was composed by more $90-95 \%$ of undifferentiated cells and did not fulfill the diagnostic criteria for other entities 5 . In 1983, Rorke ${ }^{14}$ and Becker and Hinton ${ }^{2}$ established that all CNS tumors fundamentally composed by undifferentiated neuroephitelial cells should be called PNETs. However, this concept is being controversial today. In 1993, the World Health Organization (WHO) classification recommended to use PNET term to cerebellar medulloblastoma and other CNS tumors that are histologically identical to them ${ }^{8}$. According to WHO, the PNETs are defined as embryonic tumors composed of undifferentiated or poorly differentiated neuroephitelial cells which have the capacity for or display divergent differentiation along neuronal, astrocytic, ependymal, muscular or melanotic lines ${ }^{15}$.

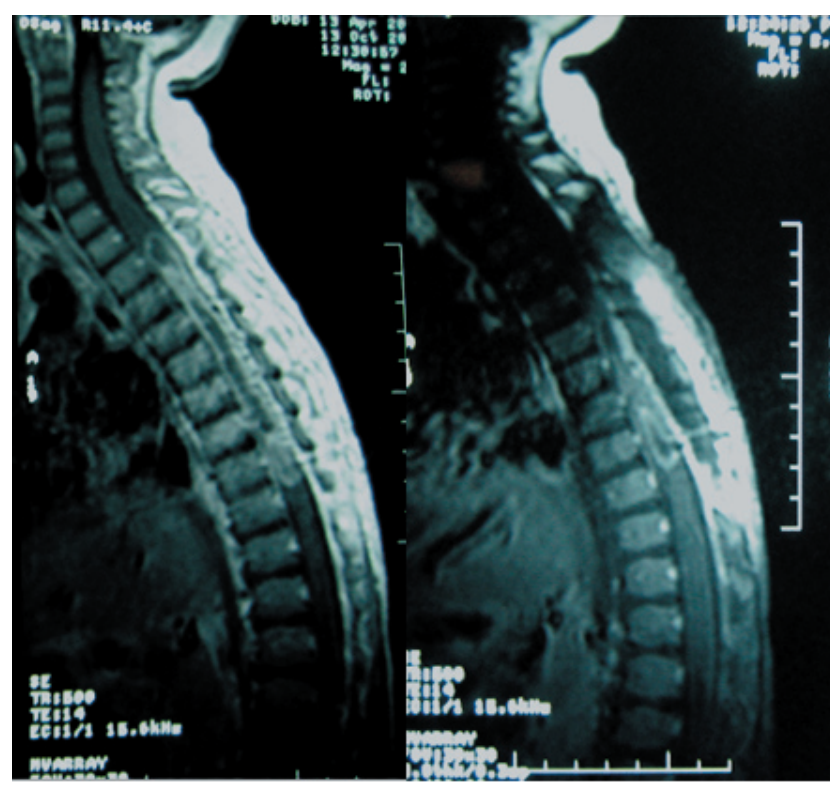

Figure 4. Postoperative magnetic resonance imaging of the spinal cord shows peripheral enhancement of the surgical cavity.

With regard to PNET involving the spinal cord, the most common are drop metastases from primary intracranial tumors, which disseminate via cerebrospinal fluid ${ }^{3}$. Primary intraspinal PNETs are rare. These neoplasms can be extradurally, extramedullary, intra-extramedullary and purely intramedullary ${ }^{3}$. Kampman et al recently found 28 cases published in the literature ${ }^{7}$. In this report, they distinguish between central PNETs and peripheral PNETs. They are tumors that have different immunohistochemical profile and genetic backgrounds. Moreover, peripheral PNETs have a potential to metastasise outside of CNS (bone, liver, lymph nodes), while central PNETs do rarely it $(<5 \%)$. However, survival rates are similar?

Only ten cases of purely IPNETs have been reported, which are summarized in table $1^{1,3,4,7,10-13,16}$. Purely IPNETs are tumors presenting mainly in children and young adults (age from 3 months to 29 years; mean 12.9 years). There are not evident sex differences (ratio female: male 1.25: 1). They can locate in any region of spinal cord (cervical, thoracic, lumbar or sacral); however, they seem to have predilection for thoracic region (77.8\% of available cases, including ours) $)^{1,3,4,10,11,13}$. It is worth standing out that four cases had wide extent through spinal cord ${ }^{4,10,11,13}$. The history of clinical presentation is short (history from 6 days to 8 weeks; mean: 3.4 weeks) ${ }^{3,7,10,16}$. Our case had an evolution of four weeks.

In seven of eight patients (87\%), progression or recurrences were reported $d^{1,3,4,7,10,11}$. They were detected within the first six months after surgery, excluding the case reported by Meltzer et al in which the recurrence occurred five 
Table 1

Summary of 11 patients with purely intramedullary PNETs

\begin{tabular}{|c|c|c|c|c|c|c|c|}
\hline Reference & Patient & Age & Sex & Level & Treatment & $\begin{array}{c}\text { Recurrence } \\
\text { Dissemination }\end{array}$ & Survival \\
\hline \multirow[t]{2}{*}{ Miller $^{12}$} & 1 & $\begin{array}{l}6 \mathrm{mo}- \\
21 \mathrm{yr}\end{array}$ & NA & NA & NA & NA & NA \\
\hline & 2 & $\begin{array}{l}6 \mathrm{mo}- \\
21 \mathrm{yr}\end{array}$ & NA & NA & NA & NA & NA \\
\hline Mottl $^{13}$ & 3 & $<17 \mathrm{yr}$ & $\mathrm{F}$ & C3-L2 & Biopsy + RT + CT & Progression & Alive \\
\hline Freyer $^{4}$ & 4 & $7 \mathrm{yr}$ & M & T4-S3 & $\begin{array}{l}\text { Biopsy + CT. CT } \\
+ \text { spinal RT after } \\
\text { progression }\end{array}$ & Progression & $20 \mathrm{mo}$ \\
\hline Osawara $^{14}$ & 5 & $16 \mathrm{yr}$ & $\mathrm{F}$ & L2 & $\begin{array}{l}\text { Removal. CT }+ \\
\text { craniospinal RT } \\
\text { after dissemination }\end{array}$ & $\begin{array}{l}\text { Intracranial } \\
\text { dissemination }\end{array}$ & $27 \mathrm{mo}$ \\
\hline Kwon $^{10}$ & 6 & $3 \mathrm{mo}$ & $\mathrm{F}$ & T7-L5 & $\begin{array}{l}\text { Biopsy. CT after } \\
\text { dissemination }\end{array}$ & $\begin{array}{l}\text { Intracranial } \\
\text { dissemination. } \\
\text { Recurrence }\end{array}$ & 15 days \\
\hline Deme $^{3}$ & 7 & $22 \mathrm{yr}$ & $\mathrm{F}$ & T12-L1 & $\begin{array}{l}\text { Removal. CT + } \\
\text { craniospinal RT } \\
\text { after recurrence }\end{array}$ & Recurrence & $\begin{array}{l}\text { Alive at } \\
5 \mathrm{mo}\end{array}$ \\
\hline Meltzer ${ }^{11}$ & 8 & $25 \mathrm{yr}$ & M & C3-conus & $\begin{array}{l}\text { Removal }+\mathrm{CT}+ \\
\text { craniospinal RT }\end{array}$ & $\begin{array}{l}\text { Recurrence } \\
\text { Intracranial } \\
\text { dissemination }\end{array}$ & $6 \mathrm{yr}$ \\
\hline Albrecht $^{1}$ & 9 & $29 \mathrm{yr}$ & $\mathrm{F}$ & T2. T10-T11 & $\begin{array}{l}\text { Biopsy }+ \\
\text { craniospinal RT }+ \\
\text { boost RT }+\mathrm{CT} \text {. } \\
\text { CT after } \\
\text { recurrence }\end{array}$ & Recurrence. & $7 \mathrm{mo}$ \\
\hline Kampman $^{7}$ & 10 & $3 \mathrm{yr}$ & M & $\mathrm{C} 2-\mathrm{C} 6$ & Biopsy & Progression & $1 \mathrm{mo}$ \\
\hline Present case & 11 & $17 \mathrm{mo}$ & M & T3-T10 & Removal + CT & $\begin{array}{l}\text { Holocord } \\
\text { progression }\end{array}$ & $\begin{array}{l}\text { Alive at } \\
6 \mathrm{mo}\end{array}$ \\
\hline
\end{tabular}

mo: months. yr: year. NA: not available. F: female. M: male. CT: chemotherapy. RT: radiotherapy

years following surgery ${ }^{11}$. Three patients $(37 \%)$ showed dissemination to the intracranial space ${ }^{10,11,16}$. Metastases outside the neuroaxis had not been detected.

The outcome is very poor. Only two of eight patients $(25 \%)$ were alive at the moment of the report, but they all showed already progression or recurrence ${ }^{3,13}$. Five of the six remaining patients died within the first 27 months: two, within the first month ${ }^{7,10}$, one, at seven months ${ }^{1}$ and two, around twenty-four months ${ }^{4,16}$. Lastly, one died at six years ${ }^{11}$. Our patient continues alive at the present (six months after surgery). Progression, recurrence or intracranal dissemination were the cause of death in most of the 
Table 2

Chemotherapeutic regimens in intramedullary PNETs

\begin{tabular}{ll} 
Reference & Chemotherapeutic regimen \\
\hline Mottl $^{13}$ & Vincristine, carboplatin, cyclophosphamide, etoposide \\
Freyer & $\begin{array}{l}\text { '8-drugs-in-a-day': vincristine, methylprednisolone, hydroxyurea, procarbazine, lomustine, Cytosine } \\
\text { araiinoside, cyclophosphamide. } \\
\end{array}$ \\
& After progression: Ifosfamide, etoposide
\end{tabular}

Osawara $^{14} \quad$ After dissemination 1: Ranimustine (MCNU), cisplatin

After dissemination 2: Cisplatin, etoposide

After dissemination 3: Carboplatin, vincristine, etoposide

After dissemination 4: Carboplatin, vincristine, adriamycin, peplomycin, cyclophosphamide

\author{
Kwon ${ }^{10} \quad$ Regimen '8-drugs-in-a-day' \\ Deme $^{3} \quad$ Vincristine, lomustine \\ After recurrence: etoposide, carboplatin, ifosphomide
}

Meltzer $^{11} \quad$ Vincristine, lomustine

Albrecht ${ }^{1} \quad$ Adriamycin, etoposide, cyclophosphamide

After recurrence: palliative chemotherapy

Present case Etoposide, cisplatin, carboplatin, cyclophosphamide, high-dose methotrexate

patients. Only one died due to pneumonia ${ }^{14}$.

The treatment of the purely IPNETs is discouraging. Most patients underwent surgery, radiotherapy and chemotherapy. In 5 of 9 cases $(55 \%)$, only a biopsy of the tumor could be accomplished ${ }^{1,3,4,7,13}$. Recurrences were both described in cases with extensive tumor resection and limited biopsies. However, similarly to medulloblastomas and whenever feasible, a maximum tumor resection is advised due to high rate of tumor recurrence ${ }^{6}$. In seven of eight patients $(87 \%)$, the treatment was completed with chemotherapy ${ }^{10,13}$ or a combination of radiotherapy and chemotherapy ${ }^{1,3,4,11,16}$. Concerning radiation therapy, $5 / 8$ cases $(62 \%)$ underwent it: four had treatment of the whole neuroaxis ${ }^{1,4,11,16}$; one, spinal radiotherapy ${ }^{4}$; and another patient had local radiotherapy ${ }^{1}$. Only two cases had radiation therapy as primary treatment after removal or biopsy ${ }^{1,11}$. The remaining received radiotherapy after progression ${ }^{4}$, recurrence ${ }^{3}$ or intracranial dissemination $^{3,11,16}$. It seems appropriate to indicate treatment of the whole neuroaxis due to high risk of progression or intracranial dissemination1. Chemotherapy was administered to all patients $\mathrm{s}^{1,3,4,10,11,13,16}$. Four patients received it as primary treatment after surgery ${ }^{1,4,11,13}$ and three cases, after recurrence, progression or intracranial dissemination ${ }^{3,10,16}$. Various multidrug chemotherapeutic regimens have been used (see Table 2). Chemotherapy is now a standard therapeutic method in patients with medulloblastoma due to the fact that maintenance chemotherapy after radiotherapy seems to deliver superior survival rates ${ }^{9}$. Chemotherapy was indicated in our patient, but radiotherapy was not administered because of patient's age. At seven reported cases of purely IPNETs in which chemotherapy or a combination of radiotherapy and chemotherapy were administered either as primary treatment or as treatment after progression, recurrence or intracranial dissemination, temporary clinical improvement have been accomplished ${ }^{1,3,4,10,11,13,16}$.

In conclusion, purely intramedullary PNETs (IPNETs) are uncommon tumors affecting children and young adults. They are characterized by recurrence, progression or intracranial dissemination. Outcome is dismal: most patients die within two years in spite of surgical resection followed by radiotherapy and chemotherapy.

\section{References}

1. Albrecht, C.F., Weiss, E., Schultz-Schaeffer, W.J. et al.: Primary intraspinal primitive neuroectodermal tumor: report of two cases and review of literature. J Neuro-Oncol 2003; 61: 113-120. 
2. Becker, L.E., Hinton, D.: Primitive neuroectodermal tumors of the central nervous system. Hum Pathol 1983; 14 : 538-550.

3. Deme, S., Ang, L.C., Skaf, G., Rowed, D.W.: Primary intramedullary primitive neuroectodermal tumor of the spinal cord: case report and review of the literature. Neurosurgery 1997; 41: 1417-1420.

4. Freyer, D.R., Hutchinson, R.J., McKeever, P.E.: Primary primitive neuroectodermal tumor of the spinal cord associated with neural tube defect. Pediatr Neurosci 1989; 15: 181-187.

5. Hart, M.N., Earle, K.M.: Primitive neuroectodermal tumors of the brain in children. Cancer 1973; 32: 890-897.

6. Jenkin, D., Goddard, K., Armstrong, D., et al.: Posterior fossa medulloblastoma in childhood: treatment results and a proposal for a new staging system. Int J Radiat Oncol Biol Phys 1991; 21: 109-122.

7. Kampman, W.A., Kros, J.M., De Jong, T.H.R., Lequin, M.H.: Primitive neuroectodermal tumors (PNETs) located in the spinal canal; the relevance of classification as central or peripheral PNET. J Neurooncol 2005; 15: 1-8.

8. Kleihues, P., Burger, P.C., Scheithauer, B.W.: The new WHO classification of brain tumors. Brain Pathology 1993; 3 : 255-268.

9. Kortmann, R.D., Kuhl, J., Timmermann, B., et al.: Postoperative neoadyuvant chemotherapy before radiotherapy as compared to immediate radiotherapy followed by maintenance chemotherapy in the treatment of medulloblastoma in childhood: results of the German prospective randomized trial HIT'91. Int J Radiat Oncol Biol Ohys 2000; 46: 269-279.

10. Kwon, O.K., Wang, K.C., Ki, I.O. et al.: Primary intramedullary spinal cord primitive neuroectodermal tumour with intracranial seeding in an infant. Child's Nerv Syst 1996; 12 :

\section{Comentario al trabajo Purely intramedullary spinal cord primitive neuroectodermal tumor: case report and review of the literature de Otero-Rodríguez et al.}

En este artículo los autores revisan, a propósito de un caso de tumor neuroectodérmico primitivo (TNEP) espinal intramedular en un niño de 17 meses de edad, las particularidades que presentan a partir de los 11 pacientes que han encontrado publicados en la literatura. El caso descrito se ciñe a las características más frecuentemente encontradas en estos pacientes, como son una corta historia clínica de 3-4 semanas de duración, la predilección por la localización medular a nivel torácico, la progresión o recurrencia de la enfermedad a pesar del tratamiento y el sombrío pronóstico. Se aleja no obstante de la media en la edad de
633-636.

11. Meltzer, C.C., Townsend, D.W., Kottapally, S., Jadali, F.: FDG imaging of spinal cord primitive neuroectodermal tumor. J Nucl Med 1998; 39: 1207-1209.

12. Miller, D.C.: Surgical pathology of intramedullary spinal cord neoplasms. J Neurooncol 2000; 47: 189-194.

13. Mottl, H., Koutecky, J.: Treatment of spinal cord tumors in children. Med Pediatr Oncol 1997; 29: 293-295.

14. Osawara, H., Kiva, K., Kurisu, K. et al.: Intracranial metastasis from a spinal cord primitive neuroectodermal tumor: case report. Surg Neurol 1992; 37: 307-312.

15. Rorke, L.B.: The cerebellar medulloblastoma and its relationship to primitive neuroectodermal tumors. J Neuropath Exp Neurol 1983; 42: 1-15.

16. Rorke, L.B., Hart, M.N., McLendon, R.E.: Supratentorial primitive neuroectodermal tumor (PNET). In Kleihues P, Cavenee WK (eds). Pathology and Genetics of Tumors of the Central Nervous System. 2000; pp. 141-144.

17. Tamber, M.S., Dirks, P.B.: Supratentorial primitive neuroectodermal tumors. In Berger MS, Prados MD (eds). Textbook of Neuro-oncology. Philadelphia; Elsevier Saunders, 2005; pp. 675-681.

Otero-Rodríguez A.; Hinojosa J.; Esparza J.; Muñoz MJ.; Iglesias S.; Rodríguez-Gil, Y.; Ricoy, J.R.: Purely intramedullary spinal cord primitive neuroectodermal tumor: case report and review of the literature. Neurocirugía 2009; 20: 381-387.

Correspondencia postal: Alvaro Otero Rodríguez. Hospital "Virgen Vega", Complejo Hospitalario de Salamanca. Paseo de San Vicente, 58-182. 37007 Salamanca.

presentación, que suelen ser propios de pacientes jóvenes, y que el tratamiento quirúrgico sólo pudo completarse con quimioterapia, influenciado sin duda por la edad temprana de presentación.

Los TNEP se incluyen en la clasificación de la OMS del año 2000 entre los tumores embrionarios, aunque su origen y criterios de clasificación histopatológica son controvertidos, se reconocen entre ellos a aquellos tumores constituidos por células redondeadas indiferenciadas y que muestran en su seno una variedad diferenciada de patrones celulares, lo que permite reconocer al meduloblastoma y al 
ependimoblastoma como los más característicos.

Las formas espinales de TNEP más frecuentes aparecen como consecuencia de la diseminación a través del líquido cefalorraquídeo de TNEP craneales. Entre los paraespinales, cola de caballo y raíces son citogenéticamente similares al sarcoma de Ewing y, sin embargo, distintos al más común en la edad infantil como el neuroblastoma. Las formas intramedulares, sin extensión extramedular intradural, ni al espacio extradural, son extraordinarias como formas de presentación de estos tumores. Aunque existen casos descritos de larga supervivencia, la cirugía, radioterapia y quimioterapia al uso más frecuentemente empleada, no permite su curación, por lo que parece necesaria la identificación de marcadores moleculares y/o genéticos que nos sirvan de dianas terapéuticas en el futuro.

Otero-Rodríguez y cols., nos presentan este inusual caso que, de forma semejante a como se describen los TNEP en la protuberancia, no puede siquiera sospecharse por las técnicas de neuroimagen, siendo precisa la muestra quirúrgica y caracterización histopatológica, no exenta de dificultad.

\section{Bibliografía}

1. Groves, M.D., Yung, W.K.A.: Systemic and intrathecal chemotherapy for tumors of the spine, spinal cord, and peripheral nerves. En Dickman CA, Fehlings MG, Gokaslan ZL (eds). Spinal cord and spinal column tumors: principles and practice. New York; Thieme Medical Publishers, 2006; pp. 171-186

2. Zazpe, I.: Metástasis intramedulares y siembras tumorales en el espacio subaracnoideo. En Grupo de Neurooncología de la SENEC (ed). Tumores raquimedulares. Madrid; Editorial Universitaria Ramón Areces, 2007; pp. 257266. 